\title{
The First Thioallenylidene Complexes from Ruthenium-Butatrienylidene Intermediates
}

\author{
Rainer F. Winter*|a]
}

\begin{abstract}
Keywords: Ruthenium / Allenylidene complexes / Butadiyne / Electrochemistry / Thio-Claisen rearrangements
\end{abstract}
Ruthenium-butatrienylidene cations trans $-\left[\mathrm{Cl}\left(\mathrm{L}_{2}\right)_{2} \mathrm{Ru}=\mathrm{C}=\mathrm{C}=\right.$ $\left.\mathrm{C}=\mathrm{CH}_{2}\right]^{+}$are key intermediates in the synthesis of the first thioallenylidene complexes trans $-\left[\mathrm{Cl}\left(\mathrm{L}_{2}\right){ }_{2} \mathrm{Ru}=\mathrm{C}=\mathrm{C}=\mathrm{C}(\mathrm{SR}) \mathrm{R}^{\prime}\right]^{+}$ $\left(L_{2}=\right.$ dppm, $R=E t, R^{\prime}=M e: 3 a, L_{2}=d p p m, R=M e, R^{\prime}=$ $\mathrm{C}_{4} \mathrm{H}_{7}: 3 \mathbf{b}, \mathrm{L}_{2}=$ dppe, $\left.\mathrm{R}=\mathrm{C}_{3} \mathrm{H}_{5}, \mathrm{R}^{\prime}=\mathrm{C}_{4} \mathrm{H}_{7}: 3 \mathbf{c}\right)$. Spectroscopic and electrochemical data for $3 \mathbf{a}-\mathbf{c}$ are presented and are compared with those of their aminoallenylidene analogues. Aminoallenylidene complexes are best represented by the iminiumalkynyl resonance form, while a true cumulene

\section{Introduction}

Despite considerable progress in the field of higher homologues of carbene complexes, ${ }^{[1]}$ as yet no stable mononuclear butatrienylidene complex has been reported. ${ }^{[2]}$ There are, however, a growing number of instances where iron or ruthenium butatrienylidene compounds are invoked as key intermediates. Following Selegue's initial report on the generation of such a species from a coordinated alkynyl ketone, ${ }^{[3]}$ we and others have elaborated a more direct access route starting from substitutionally labile iron or ruthenium precursors $[\mathrm{Cp} * \mathrm{Fe}(\mathrm{dppe}) \mathrm{Cl}],\left[\mathrm{CpRu}\left(\mathrm{PPh}_{3}\right)_{2} \mathrm{Cl}\right]$, or cis$\left[\mathrm{Cl}_{2} \mathrm{Ru}\left(\mathrm{L}_{2}\right)_{2}\right]\left(\mathrm{L}_{2}=\mathrm{dppm}\right.$, depe $)$ and butadiyne. The reactivity of the $\mathrm{C}_{4} \mathrm{H}_{2}$ ligand is dominated by the alternation of electrophilic and nucleophilic carbon centers and the easy access to the sterically unprotected terminal $\mathrm{C}=\mathrm{C}$ bond. Apart from remarkable cycloaddition-cycloreversion sequences with aromatic imines, ${ }^{[4]}$ two major reaction types have been identified so far: (i) regioselective addition of protic nucleophiles to the terminal $\mathrm{C}_{\gamma}=\mathrm{C}_{\delta}$ bond to give methylsubstituted allenylidene complexes, ${ }^{[5]}$ and (ii) regioselective addition of aprotic nucleophiles to the electron-deficient $\mathrm{C}_{\gamma}$, $\mathrm{C}_{\alpha}$ being sterically protected by the bulky phosphane coligands on ruthenium. ${ }^{[5-7]}$ The initial addition step may be followed by tautomerization, ${ }^{\left[{ }^{a}, \mathrm{~b}\right]}$ Cope-type rearrangements of quaternary vinylammonium salts resulting from the addition of allylic amines, ${ }^{[6 a]}$ or by a shift of the resonance stabilized ferrocenylmethyl cation to the neighbouring nucleophilic $\mathrm{C}_{\delta}$ to give an aminoallenylidene complex with an appended redox-active substituent. ${ }^{[7]}$ We report herein on the successful synthesis of the first thioallenylidene complexes $\left[\{\mathrm{Ru}\}=\mathrm{C}=\mathrm{C}=\mathrm{C}(\mathrm{SR}) \mathrm{R}^{\prime}\right]^{+}$from butatrienylidene intermediates.

\footnotetext{
[a] Institut für Anorganische Chemie der Universität Stuttgart, Pfaffenwaldring 55, D-70569 Stuttgart, Germany

E-mail: winter@iac.uni-stuttgart.de
}

description is much more appropriate for thioallenylidene complexes 3a-c. Based on a combination of spectroscopic and electrochemical data, we present evidence that the NMR shifts of the carbon atoms of the unsaturated ligand in these allenylidene complexes are correlated to the HOMO-LUMO gap. In situ EPR-, UV/Vis-, and IR-spectro-electrochemistry reveals that the one-electron oxidation occurs at the metal center, while reduction occurs at the carbon-heteroatom terminus.

\section{Results and Discussion}

We have successfully employed both fundamental strategies, i.e. the regioselective addition of a protic nucleophile (a thiol) and the addition of aprotic nucleophiles (allylic thioethers) with subsequent $[3,3]$ thio-Claisen rearrangement, to effect the synthesis of trans $-\left[\mathrm{Cl}\left(\mathrm{L}_{2}\right)_{2} \mathrm{Ru}=\mathrm{C}=\mathrm{C}=\right.$ $\left.\mathrm{C}(\mathrm{SR}) \mathrm{R}^{\prime}\right]^{+} \mathrm{X}^{-}\left(\mathbf{3 a}-\mathrm{c}, \mathrm{L}_{2}=\mathrm{dppm}\right.$, dppe, $\mathrm{X}^{-}=\mathrm{SbF}_{6}{ }^{-}$, OTf $^{-}$, Scheme 1), the first examples of thioallenylidene complexes. Their identities have been unequivocally established by spectroscopic means. The trans arrangement of the chloride and allenylidene ligands follows directly from the observation of two $\mathrm{ABX}_{2} \mathrm{X}_{2}^{\prime}$ spin systems for the methylene groups of the dppm ligand and single sharp singlets in the respective ${ }^{31} \mathrm{P}-\mathrm{NMR}$ spectra. Our spectroscopic data place the intense yellow-green $(3 \mathbf{a}, \mathbf{b})$ or red $(3 \mathbf{c})$ thioallenylidene complexes close to "conventional" allenylidene analogues without a heteroatom substituent attached to $\mathrm{C}_{\gamma}$. This is exemplified by the intense IR stretch of the $\mathrm{C}=\mathrm{C}=$ $\mathrm{C}$ unit, which is found at ca. $1940 \mathrm{~cm}^{-1}$ for $3 \mathrm{a}-\mathbf{c}$, at 1995 $\mathrm{cm}^{-1}$ for aminoallenylidene complexes, ${ }^{[6,7]}$ at $1955 \mathrm{~cm}^{-1}$ for alkyloxy-substituted allenylidene complexes, ${ }^{[8]}$ and at ca. 1920 to $1950 \mathrm{~cm}^{-1}$ for aryl- or alkyl-substituted allenylidene complexes of the same metal fragment. ${ }^{[9]}$

There is ample precedent that aminoallenylidene complexes are best represented by the iminiumalkynyl resonance form $\mathbf{B}^{[6,10,11]}$ This is not only evident from the position of the $\mathrm{C}=\mathrm{C}=\mathrm{C}$ stretch in the IR spectrum and the ${ }^{13} \mathrm{C}$ data (vide infra), but also from the two separate resonance signals seen for the identical substituents on the iminium nitrogen atom. High-temperature $\mathrm{NMR}$ studies on trans$\left[\mathrm{Cl}(\mathrm{dppm})_{2} \mathrm{Ru}-\mathrm{C} \equiv \mathrm{C}-\mathrm{C}\left(=\mathrm{NMe}_{2}\right) \mathrm{C}_{2} \mathrm{H}_{4} \mathrm{CH}=\mathrm{CH}_{2}\right]^{+} \mathrm{PF}_{6}{ }^{-}$ (4a) and its depe-substituted counterpart $4 \mathrm{~b}$ reveal that even at $368 \mathrm{~K}$ in $\mathrm{CD}_{3} \mathrm{NO}_{2}$ the two $\mathrm{NMe}$ resonances remain separate and sharp. From this, the barrier to rotation about this $\mathrm{C}=\mathrm{N}$ bond can be estimated to be well above 71 and 76 $\mathrm{kJ} \mathrm{mol}^{-1}$, respectively. On the other hand, thioallenylidene 

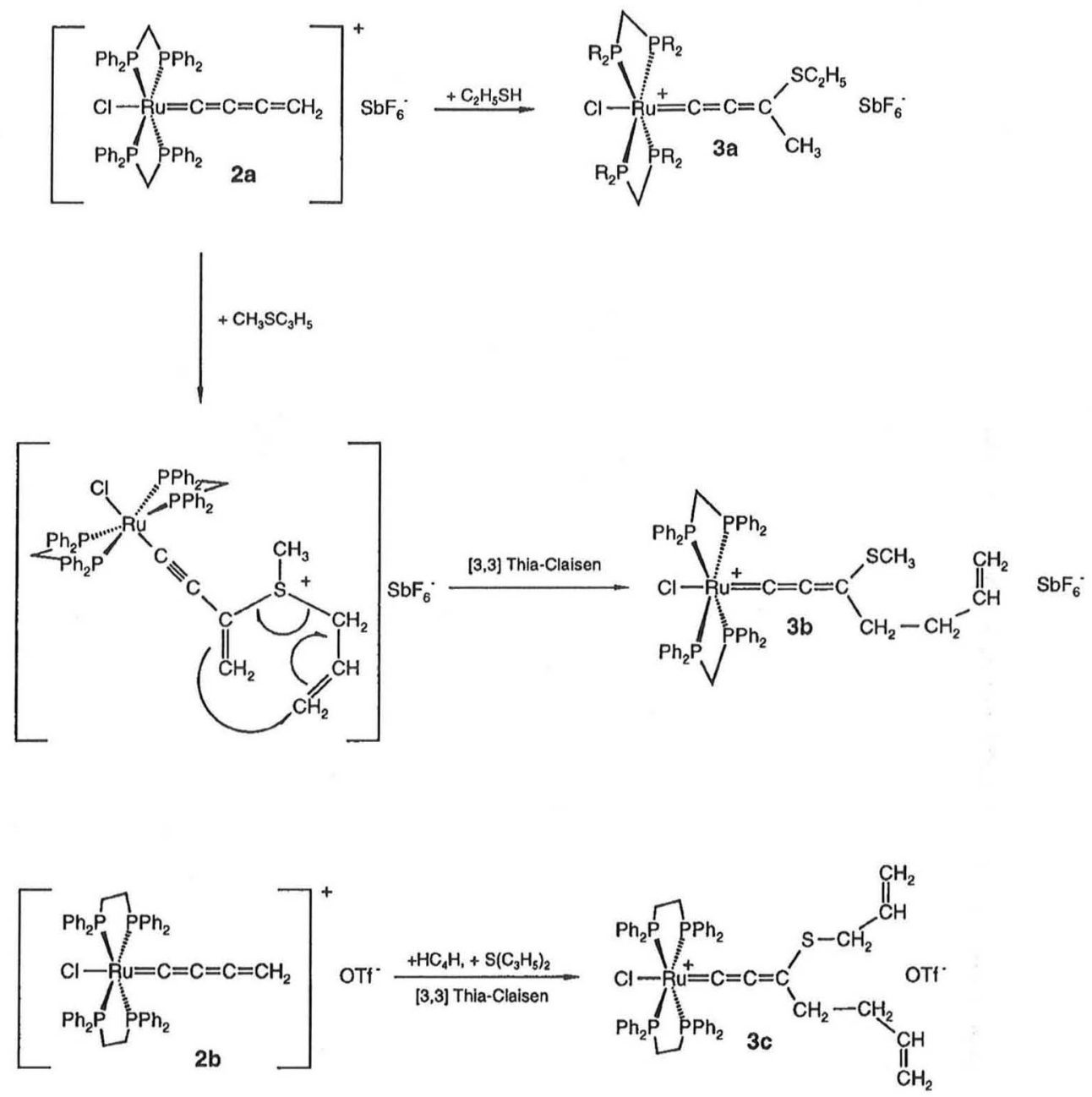

Scheme 1. Synthesis of the thioallenylidene complexes $3 \mathbf{a}-\mathbf{c}$

complexes $3 \mathbf{a}-\mathbf{c}$ are adequately described by the true allenylidene resonance form $\mathbf{A}$.

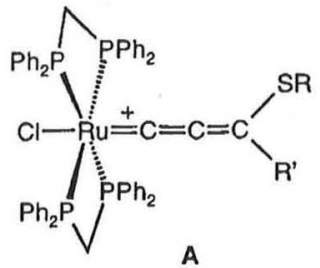<smiles>[R]C(C#C[C@](Cl)(P([PH])c1ccccc1)P(c1ccccc1)c1ccccc1)=[N+]([2H])[2H]</smiles>

The ${ }^{13} \mathrm{C}$-NMR signals of the carbon atoms of the unsaturated ligands in $3 \mathbf{a}-\mathbf{c}$ are readily discernible and may be assigned by virtue of the $\mathrm{P}-\mathrm{C}$ coupling constants and the chemical shift values. For other heteroatom-substituted allenylidene complexes, both are known to decrease with increasing distance from the metal center. ${ }^{[5-8]}{ }^{13} \mathrm{C}-\mathrm{NMR}$ data for a variety of allenylidene complexes containing the trans$\left[\mathrm{ClRu}(\mathrm{dppm})_{2}\right]^{+}$fragment are collected in Table 1. The following trends emerge: (i) All three carbon atom signals of the cumulene chain are subject to a progressive downfield shift in the order $\mathrm{NR}_{2}<\mathrm{OR}<\mathrm{SR}<\mathrm{CR}_{3}$. (ii) The influence of the heteroatom on the shift values decreases with increasing distance from the metal center, with the substituted $\mathrm{C}_{\gamma}$ being rather insensitive to the nature of the atom attached to it. Thus, the shift differences $\Delta \delta$ for equivalent carbon atoms in all-carbon and amino-substituted allenylidene complexes, which constitute the two extremes in Table 1, amount to ca. $120 \mathrm{ppm}$ for $\mathrm{C}_{\alpha}, 90 \mathrm{ppm}$ for $\mathrm{C}_{\beta}$, but less than $20 \mathrm{ppm}$ for $\mathrm{C}_{\gamma}$.

It has long been known that the characteristic low-field shifts of metal-bound carbene, vinylidene, and cumulenylidene carbon atoms (and obviously also to a lesser degree of $\mathrm{C}_{\beta}$ ) are induced by the paramagnetic term, which itself is related to the HOMO-LUMO gap. ${ }^{[12]}$ We observe a clear manifestation of this trend upon comparison of the electrochemical and optical data for the novel thioallenylidene complexes $3 \mathbf{a}-\mathbf{c}$ and those for our aminoallenylidene cations trans- $\left[\mathrm{Cl}(\mathrm{dppm})_{2} \mathrm{Ru}-\mathrm{C} \equiv \mathrm{C}-\mathrm{C}\left(=\mathrm{NMe}_{2}\right) \mathrm{C}_{2} \mathrm{H}_{4} \mathrm{R}\right]^{+}$ $\left[\mathrm{R}=\mathrm{CH}=\mathrm{CH}_{2}: 4 \mathrm{a}, \mathrm{R}=\left(\eta^{5}-\mathrm{C}_{5} \mathrm{H}_{4}\right) \mathrm{Fe}\left(\eta^{5}-\mathrm{C}_{5} \mathrm{H}_{5}\right), \mathrm{Fc}: 4 \mathbf{c}\right.$, Table 2]. ${ }^{[6,7]}$ All the complexes undergo well-defined oneelectron oxidations and one-electron reductions at potentials that are clearly dependent on the heteroatom attached 
Table $1 .{ }^{13} \mathrm{C}-\mathrm{NMR}$ data for the allenylidene carbon atoms of complexes $\left[\{\mathrm{Ru}\}=\mathrm{C}=\mathrm{C}=\mathrm{C}\left(\mathrm{ER}_{\mathrm{n}}\right) \mathrm{R}^{\prime}\right]^{+}\left[\{\mathrm{Ru}\}=\operatorname{trans}-\left\{\mathrm{ClRu}(\mathrm{dppm})_{2}\right\}^{+}\right]$

\begin{tabular}{|c|c|c|c|c|c|}
\hline $\mathrm{ER}_{n}$ & $\mathrm{R}^{\prime}$ & $\delta\left(\mathrm{C}_{\alpha}\right)\left({ }^{2} J_{\mathrm{P}-\mathrm{C}}\right)^{[\mathrm{a}]}$ & $\delta\left(\mathrm{C}_{\beta}\right)\left({ }^{3} J_{\mathrm{P}-\mathrm{C}}\right)$ & $\delta\left(\mathrm{C}_{\gamma}\right)\left({ }^{4} J_{\mathrm{P}-\mathrm{C}}\right)$ & ref. \\
\hline $\mathrm{N}\left(\mathrm{CH}_{3}\right)_{2}$ & $\mathrm{C}_{2} \mathrm{H}_{4} \mathrm{CH}=\mathrm{CH}_{2}$ & 202.09 (13.9) & $118.73(2.2)$ & $156.91(-)$ & [6] \\
\hline $\mathrm{N}\left(\mathrm{CH}_{3}\right)_{2}$ & $\mathrm{C}_{2} \mathrm{H}_{4} \mathrm{Fc}^{[\mathrm{b}]}$ & $201.8(13.6)$ & $119.4(2.4)$ & $156.7(-)$ & [7] \\
\hline $\mathrm{OCH}_{3}$ & $\mathrm{CH}=\mathrm{C}\left(\mathrm{C}_{6} \mathrm{H}_{5}\right)_{2}$ & 252.8 (13.6) & $150.2(2.2)$ & $155.7(-)$ & [9] \\
\hline $\mathrm{SCH}_{3}$ & $\mathrm{C}_{2} \mathrm{H}_{4} \mathrm{CH}=\mathrm{CH}_{2}$ & 283.5 (13.4) & $169.5(2.4)$ & $171.1(1.5)$ & this work \\
\hline $\mathrm{SC}_{2} \mathrm{H}_{5}$ & $\mathrm{CH}_{3}$ & $286.2(13.6)$ & $172.1(2.3)$ & $168.3(1.65)$ & this work \\
\hline $\mathrm{CH}_{3}$ & $\mathrm{CH}_{3}$ & $322.69(13.9)$ & $199.85(2.3)$ & $173.33(-)$ & {$[10]$} \\
\hline $\mathrm{C}_{6} \mathrm{H}_{5}$ & $\mathrm{C}_{6} \mathrm{H}_{5}$ & 307.33 (14.3) & 208.94 (2.5) & $161.88(-)$ & {$[10]$} \\
\hline
\end{tabular}

[a] $\delta[\mathrm{ppm}], J[\mathrm{~Hz}] .-{ }^{\text {[b] }} \mathrm{Fc}=\left(\eta^{5}-\mathrm{C}_{5} \mathrm{H}_{4}\right) \mathrm{Fe}\left(\eta^{5}-\mathrm{C}_{5} \mathrm{H}_{5}\right)$.

to $\mathrm{C}_{\gamma}$ (Table 2). As is evident from a comparison of the $\mathrm{CV}$ traces shown in Figure 1, replacing $\mathrm{NR}_{2}$ by SR substituents induces significant cathodic shifts in the oxidation and reduction potentials of 0.3 and $0.8 \mathrm{~V}$, respectively. As one may infer from these data, the LUMO is preferentially lowered with respect to the HOMO which, of course, reduces the HOMO-LUMO gap. As a consequence, the energies of the intense optical absorptions in the visible part of the spectra decrease considerably in this series. For aminoallenylidene complexes, this band apparently has some metal-to-ligand charge-transfer (MLCT) character, as indicated by the negative solvatochromism of the order of some 450 to 720 $\mathrm{cm}^{-1}$. In contrast, no such effect is apparent for thioallenylidene complexes $3 \mathbf{a}-\mathbf{c}$. Optical transition energies consistently exceed those measured by electrochemical methods. This is due to the vertical excitation involved in the optical transition (Franck-Condon principle) as compared to the "true" energy difference between the vibrationally relaxed ground and excited states determined by electrochemical methods. The energy difference $\Delta E_{\mathrm{op}}-\Delta E_{\mathrm{ec}}$ provides a measure of the vibrational excitation associated with the optical transition and therefore of the degree of structural reorganization required upon excitation, and is parameterized as the structural factor $\Delta \chi$ (Equation 1). ${ }^{[13]}$

$\Delta E_{\mathrm{op}}=\Delta E_{\mathrm{ec}}+\Delta \chi$

In our heteroatom-substituted allenylidene complexes of the dppm ligand, $\Delta \chi$ amounts to 0.46 to $0.47 \mathrm{eV}$, indicating a moderate degree of structural rearrangement on going from the ground to the excited states. The fact that other values of $\Delta \chi$ are found for complexes with diphosphane chelate ligands other than dppm suggests that the predominant structural change occurs at the metal fragment. Unfortunately, no UV/Vis data have been reported for any other allenylidene complexes containing the trans-
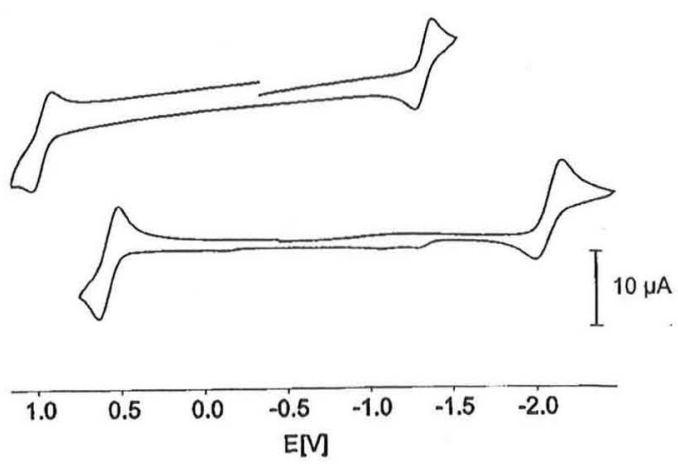

Figure 1. CV traces of trans-[Cl(dppm $)_{2} \mathrm{Ru}-\mathrm{C} \equiv \mathrm{C}-\mathrm{C}=$ $\left.\left(\mathrm{NMe}_{2}\right) \mathrm{C}_{4} \mathrm{H}_{7}\right]^{+}(4 \mathrm{a})$ at $231 \mathrm{~K}$ and $v=1 \mathrm{~V} / \mathrm{s}$ (lower trace) and trans$\left[\mathrm{Cl}(\mathrm{dppm})_{2} \mathrm{Ru}=\mathrm{C}=\mathrm{C}=\mathrm{C}=(\mathrm{SMe}) \mathrm{C}_{4} \mathrm{H}_{7}\right]^{+}(3 \mathrm{~b})$ at $273 \mathrm{~K}$ and $v=0.2$ $\mathrm{V} / \mathrm{s}$ (upper trace) in $\mathrm{CH}_{3} \mathrm{CN}$

$\left[\mathrm{Cl}(\mathrm{dppm})_{2} \mathrm{Ru}\right]^{+}$fragment. Judging, however, from the colours (alkyloxy-substituted allenylidene complexes are orange, while all-carbon substituted analogues are violet to purple ${ }^{[8,9]}$ and the optical data for the closely related $\left[\mathrm{CpRu}\left(\mathrm{PPh}_{3}\right)_{2}\right]^{+}$derivatives, ${ }^{[14]}$ we conclude that the HOMO-LUMO gap decreases in the series $\mathrm{NR}_{2}>\mathrm{OR}>$ $\mathrm{SR}>\mathrm{CR}_{3}$, thus providing a rationale for the observed trends in the ${ }^{13} \mathrm{C}$-NMR data.

The differences in redox potentials also have a bearing on the chemical stabilities of the oxidation and reduction products (see Figure 1). For the aminoallenylidene complexes $4 \mathbf{a}, \mathbf{c}$ and the depe derivative trans- $\left[\mathrm{Cl}(\text { depe })_{2-}\right.$ $\left.\mathrm{Ru}-\mathrm{C} \equiv \mathrm{C}-\mathrm{C}\left(=\mathrm{NMe}_{2}\right) \mathrm{C}_{2} \mathrm{H}_{4} \mathrm{CH}=\mathrm{CH}_{2}\right]^{+} \quad(4 \mathrm{~b})$, the oxidation process is fully reversible, while for the reduction low temperature and sweep rates of about $1 \mathrm{~V} / \mathrm{s}$ are required to allow the observation of an associated return peak. ${ }^{[7]}$ For thioallenylidene complexes $3 \mathbf{a}-\mathbf{c}$, on the other hand, just the opposite order of stabilities is observed. This makes the oxidation products of $4 \mathbf{a}-\mathbf{c}$ and the reduction products of

Table 2. UV/Vis and electrochemical data for amino- and thio-substituted allenylidene cations trans- $\left[\mathrm{ClRu}(\mathrm{L})_{2} \mathrm{C}=\mathrm{C}=\mathrm{C}\left(\mathrm{ER}{ }_{n}\right) \mathrm{R}^{\prime}\right]^{+}$

\begin{tabular}{|c|c|c|c|c|c|c|c|c|}
\hline $\mathrm{ER}_{n}$ & $\mathrm{R}^{\prime}$ & $\mathrm{L}$ & $v_{\max }\left[\mathrm{cm}^{-1}\right]\left(\log \varepsilon_{\max }\right)$ & $E_{1 / 2}+/ 2+[\mathrm{V}]$ & $E_{1 / 2}{ }^{+/ 0}[\mathrm{~V}]$ & $\Delta E_{\mathrm{op}}[\mathrm{eV}]$ & $\Delta E_{\mathrm{ec}}[\mathrm{V}]$ & $\Delta \chi[\mathrm{eV}]$ \\
\hline $\mathrm{NMe}_{2}$ & $\mathrm{C}_{4} \mathrm{H}_{7}$ & dppm & $25575(4.230)$ & +0.57 & -2.14 & 3.17 & 2.71 & 0.46 \\
\hline $\mathrm{NMe}_{2}$ & $\mathrm{C}_{2} \mathrm{H}_{4} \mathrm{Fc}$ & $\mathrm{dppm}$ & $25900(4.361)$ & +0.62 & -2.13 & 3.21 & 2.75 & 0.46 \\
\hline $\mathrm{NMe}_{2}$ & $\mathrm{C}_{4} \mathrm{H}_{7}$ & depe & $25060(4.380)$ & +0.42 & $<-2.20$ & 3.11 & $>2.62$ & $<0.49$ \\
\hline SEt & $\mathrm{Me}$ & dppm & $21740(3.919)$ & +0.850 & -1.375 & 2.695 & 2.225 & 0.47 \\
\hline SMe & $\mathrm{C}_{4} \mathrm{H}_{7}$ & dppm & $21505(4.209)$ & +0.865 & -1.355 & 2.665 & 2.220 & 0.465 \\
\hline SAllyl & $\mathrm{C}_{4} \mathrm{H}_{7}$ & dppe & $21230(4.230)$ & +0.985 & -1.275 & 2.63 & 2.26 & 0.37 \\
\hline
\end{tabular}


3a-c amenable to spectroscopic characterization. Such investigations can be expected to provide information on the oxidation and reduction sites within these allenylidene complexes. In their EPR spectra at $110 \mathrm{~K}$ and $4 \mathrm{~K}$, electrochemically oxidized samples of $4 \mathbf{c}$ exhibit an axial pattern at $g_{\|}=2.400$ and $g_{\perp}=2.067$, respectively. No EPR signals were observed for $\mathbf{4 a}$. The rather low intensity of the EPR signals and the considerable spread of $g$ values are both supportive of an assignment to an Ru-based radical, such that the oxidation may be viewed as essentially involving a ruthenium(II/III) redox couple. This is also in accord with our observation that fully oxidized trans$\left[\mathrm{Cl}(\mathrm{dppm})_{2} \mathrm{Ru}-\mathrm{C} \equiv \mathrm{C}-\mathrm{C}\left(=\mathrm{NMe}_{2}\right) \mathrm{C}_{2} \mathrm{H}_{4} \mathrm{Fc}\right]^{3+}$ (4c) displays an intense triplet signal at $g=2.0064$ arising from coupling of the ferrocinium subunit to a paramagnetic $\mathrm{Ru}$ (III) center, giving too weak a signal to be observed directly. The same conclusion has already been reached from UV/Vis and IR spectro-electrochemical studies of this complex. ${ }^{[7]}$

In the frozen state, the reduced form of the thio-substituted allenylidene complex $\mathbf{3 b}$ exhibits a broadened isotropic signal at $g=2.0031$, i.e. in a region characteristic of organic radicals. On warming to $295 \mathrm{~K}$, the spectrum gradually resolves into a quintet of triplets, which we successfully simulated assuming coupling constants of 9.86 and 6.60 Gauss (Figure 2). This coupling pattern points to the reduction occurring at the heteroatom-substituted terminus of the allenylidene ligand. The triplet splitting then arises from coupling to the neighbouring methylene group, and the quintet from coupling to the four equivalent phosphorus nuclei across the cumulene bridge. From the resonance form for reduced $\mathbf{3 b}$ shown in Figure 2, one would expect an increase in bond order of the $\mathrm{C}_{\alpha}-\mathrm{C}_{\beta}$ bond from $\mathrm{C}=\mathrm{C}$ to $\mathrm{C} \equiv \mathrm{C}$ upon reduction. On following this process by IR spectro-electrochemistry, the intense allenylidene band does indeed gradually disappear, which is accompanied by the concomitant formation of a new, much weaker feature at $2048 \mathrm{~cm}^{-1}$ (Figure 3). The position of this band is characteristic of alkynyl complexes of the trans$\left[\mathrm{Cl}(\mathrm{dppm})_{2} \mathrm{Ru}\right]^{+}$fragment. ${ }^{[8]} \mathrm{A}$ severe reduction in absorptivity on going from allenylidene to alkynyl ${ }^{[8]}$ and from cationic to neutral complexes ${ }^{[15]}$ has already been described in the literature. We should state that even in our best runs the reduction was accompanied by some decomposition, as indicated by the fact that only $60 \%$ of the initial band intensity was regained upon reoxidation. Nevertheless, we are certain that the observed band at $2048 \mathrm{~cm}^{-1}$ originates from the reduced counterpart of $\mathbf{3 b}$ since, upon reoxidation, this band gradually disappears while the original band is partly restored.

In situ UV/Vis spectro-electrochemical experiments require lower concentrations and therefore shorter electrolysis times. Thus, the reduction/reoxidation cycle of $\mathbf{3 b}$ proceeded with more than $90 \%$ recovery of the starting material. Upon reduction, the intense allenylidene band at $\lambda=465 \mathrm{~nm}$ disappears and is replaced by a less intense absorption (log $\varepsilon=3.980$ ) at ca. $306 \mathrm{~nm}$, a region characteristic for $\mathrm{Ru}(\mathrm{II})$ - alkynyl complexes (Figure 4). We have observed bands with similar positions and intensities for the related

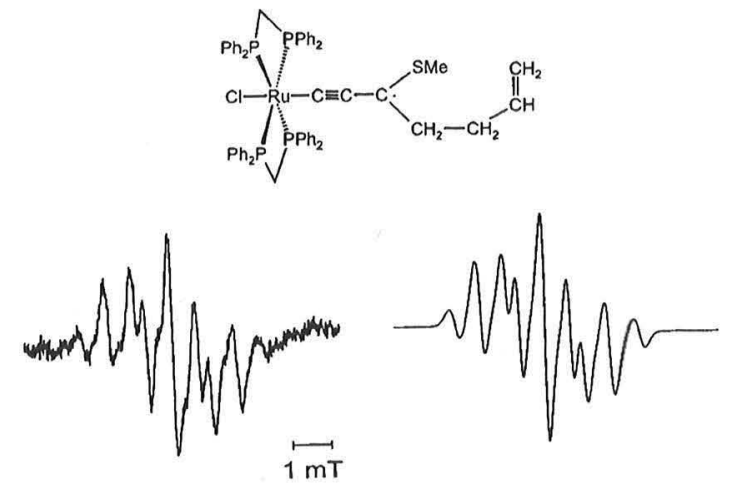

Figure 2. Experimental and simulated EPR spectra of in situ generated trans $-\left[\mathrm{Cl}(\mathrm{dppm})_{2} \mathrm{Ru}-\mathrm{C} \equiv \mathrm{C}-\mathrm{C}=(\mathrm{SMe}) \mathrm{C}_{4} \mathrm{H}_{7}\right]^{\circ}$ at $295 \mathrm{~K}$

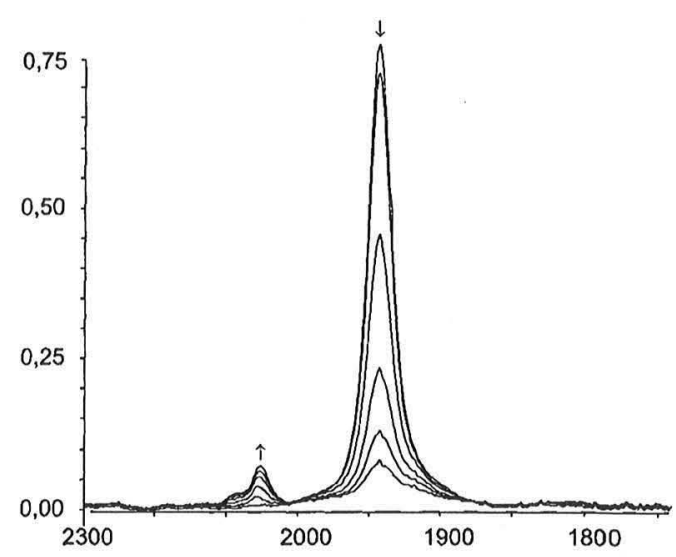

Figure 3. IR spectroscopic changes during the reduction of trans$\left[\mathrm{Cl}(\mathrm{dppm})_{2} \mathrm{Ru}=\mathrm{C}=\mathrm{C}=\mathrm{C}=(\mathrm{SMe}) \mathrm{C}_{4} \mathrm{H}_{7}\right]^{+}(3 \mathbf{b})$

ammoniobutenynyl complexes trans- $\left[\mathrm{ClRu}(\mathrm{dppm})_{2}-\mathrm{C} \equiv \mathrm{C}-\mathrm{C}\right.$ $\left.\left(\mathrm{NR}_{2} \mathrm{R}^{\prime}\right)=\mathrm{CH}_{2}\right]^{+}$that result from the trapping of butatrienylidene complexes with tertiary aliphatic or benzylic amines. ${ }^{[6]}$ Furthermore, the $n-\pi^{*}$ type transition originating from the dppm ligand is shifted from $271 \mathrm{~nm}$ to $263 \mathrm{~nm}$ while largely retaining its absorptivity. All this points to reduction of thioallenylidene complexes $3 \mathbf{a}-\mathbf{c}$ occurring at the $\mathrm{C}$-heteroatom terminus of the unsaturated ligand, with accompanying changes in the CCC bonding mode.

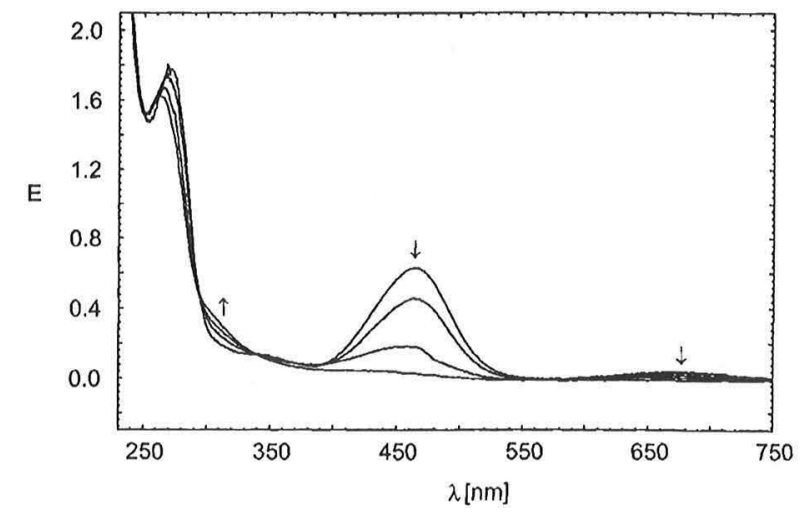

Figure 4. UV/Vis spectroscopic changes during the reduction of trans $-\left[\mathrm{Cl}(\mathrm{dppm})_{2} \mathrm{Ru}=\mathrm{C}=\mathrm{C}=\mathrm{C}=(\mathrm{SMe}) \mathrm{C}_{4} \mathrm{H}_{7}\right]^{+}(\mathbf{3 b})$ 
In summary, we have described the first thio-substituted allenylidene complexes. They are formed by the trapping of Ru-butatrienylidene intermediates by thiols or allylic thioethers. This provides a further example of the utilization of such intermediates in the synthesis of highly unsaturated and functionalized, yet stable ligands. A comparison of the optical, ${ }^{13} \mathrm{C}$-NMR, and electrochemical data of a series of allenylidene complexes provides a rationale for the observed trend in the ${ }^{13} \mathrm{C}-\mathrm{NMR}$ shifts $\left(\mathrm{NR}_{2}<\mathrm{OR}<\mathrm{SR}<\mathrm{CR}_{3}\right)$ as arising from the decreasing HOMO-LUMO gap within this series. In situ spectro-electrochemical investigations of the oxidized forms of amino-substituted complexes $4 \mathbf{b}, \mathbf{c}$ and the reduced form of the thioallenylidene complex $\mathbf{3 b}$ have allowed identification of the oxidation and reduction sites within these complexes. Oxidation occurs at the metal center, while the reduction occurs at the $C$-heteroatom terminus and thus at the opposite end of the cumulenic chain. Our findings are in full agreement with EHMO calculations on the cationic allenylidene complexes $\left[\eta^{5}-\mathrm{C}_{5} \mathrm{H}_{5} \mathrm{Ru}-\right.$ $\left.(\mathrm{CO})\left(\mathrm{PH}_{3}\right)=\mathrm{C}=\mathrm{C}=\mathrm{CH}_{2}\right]^{+[16 \mathrm{a}]}$ and $\left[\eta^{5}-\mathrm{C}_{9} \mathrm{H}_{7} \mathrm{Ru}\left(\mathrm{PH}_{3}\right)_{2}=\right.$ $\left.\mathrm{C}=\mathrm{C}=\mathrm{CH}_{2}\right]^{+},{ }^{[16 \mathrm{~b}]}$ Both indicate that the HOMO is dominated by contributions from the $\mathrm{Ru}$ d-orbitals, while the LUMO is mainly localized on the unsaturated ligand. We now aim to extend our investigations to differently substituted allenylidene complexes in order to probe the general validity of our conclusions.

\section{Experimental Section}

All manipulations were performed by standard Schlenk techniques under argon atmosphere. Dichloromethane, hexanes, and acetonitrile were dried by distillation from $\mathrm{CaH}_{2}$. All solvents were deoxygenated either by at least three freeze-pump-thaw cycles or by saturating with argon prior to use. $\left[\mathrm{RuCl}_{2}(\mathrm{dmso})_{4}\right]^{[17]}$ and cis$\left[\mathrm{RuCl}_{2}(\mathrm{dppm})_{2}\right](1)^{[18]}$ were obtained according to literature methods. Butadiyne was prepared from 1,4-dichlorobut-2-yne (Lancaster) on a $4 \mathrm{mmol}$ scale by a slight modification of a published procedure ${ }^{[19]}$ and was isolated at $195 \mathrm{~K}$ as a white crystalline solid. CAUTION: Butadiyne should be handled and stored under rigorous exclusion of air and at temperatures below $230 \mathrm{~K}$. Prior to use it was thawed in an ice/ $\mathrm{CaCl}_{2}$ cooling bath and the required amount (ca. $600 \mu \mathrm{L}$ ) was transferred via a precooled pipette. NMR: Bruker AC 250. - IR: Elmer Paragon 1000 PC. - UV/Vis: Shimadzu UV-160 or Omega 10 from Bruins Instruments. - EPR: Bruker ESP 3000, HP frequency counter 5350 B, Bruker NMR gaussmeter ER $035 \mathrm{M}$, with a continuous flow cryostat ESR 900 from Oxford Instruments for low-temperature work. Electrochemistry was performed as described in an earlier publication. ${ }^{20]}$

Preparation of trans $-\left[\mathrm{ClRu}(\mathrm{dppm})_{2}=\mathrm{C}=\mathrm{C}=\mathrm{C}(\mathrm{SEt}) \mathrm{Me}^{+} \mathrm{SbF}_{6}{ }^{-}\right.$ (3a): To a suspension of $171 \mathrm{mg}(0.18 \mathrm{mmol})$ of $c i s-\left[\mathrm{RuCl}_{2}(\mathrm{dppm})_{2}\right]$ (1) and $379 \mathrm{mg}(1.46 \mathrm{mmol})$ of $\mathrm{NaSbF}_{6}$ in $40 \mathrm{~mL}$ of $\mathrm{CH}_{2} \mathrm{Cl}_{2}$, excess butadiyne (ca. $600 \mu \mathrm{L}$ ) was added by syringe. After the colour of the suspension had changed to green, $160 \mu \mathrm{L}(2.16 \mathrm{mmol})$ of EtSH was added by syringe. The resulting solution was stirred under ambient conditions for $23 \mathrm{~h}$, then filtered, and concentrated to dryness. The residue was thoroughly washed with hexanes. The crude product was then redissolved in chloroform and this solution was stirred at $50^{\circ} \mathrm{C}$ for 3 days. After evaporation of the solvent, the crude material was chromatographed on silica gel $\left(4 \% \mathrm{H}_{2} \mathrm{O}\right.$, col- umn $14 \times 3 \mathrm{~cm}$ ). The product was eluted with $\mathrm{CH}_{2} \mathrm{Cl}_{2} / \mathrm{CH}_{3} \mathrm{CN}$, $8: 1$, as a yellow-green band. The solvents were removed in vacuo and the remaining green solid was washed with hexanes and dried in vacuo; $72 \mathrm{mg}(32 \%)$. - ' $\mathrm{H}$ NMR $\left(\mathrm{CDCl}_{3}\right): \delta=0.73[\mathrm{t}, 3 \mathrm{H}$, $\left.\mathrm{SCH}_{2} \mathrm{CH}_{3},{ }^{3} \mathrm{~J}(\mathrm{HH})=7.54 \mathrm{~Hz}\right], 1.10\left(\mathrm{~s}, 3 \mathrm{H}, \mathrm{CH}_{3}\right), 1.62[\mathrm{q}, 2 \mathrm{H}$, $\mathrm{SCH}_{2},{ }^{3} \mathrm{~J}(\mathrm{HH})=7.54 \mathrm{~Hz}$ ] 5.00 [dquint, $2 \mathrm{H}, \mathrm{CH}_{2}(\mathrm{dppm})$, $J(\mathrm{HH})=15.46 \mathrm{~Hz},{ }^{2} J(\mathrm{PH})={ }^{4} J\left(\mathrm{P}^{\prime} \mathrm{H}\right)=4.10 \mathrm{~Hz}$ ], 5.26 [dquint, 2 $\left.\mathrm{H}, \mathrm{CH}_{2}(\mathrm{dppm}), J(\mathrm{HH})=15.46 \mathrm{~Hz},{ }^{2} J(\mathrm{PH})={ }^{4} J\left(\mathrm{P}^{\prime} \mathrm{H}\right)=5.00 \mathrm{~Hz}\right]$, $7.13\left[\mathrm{t}, 8 \mathrm{H}\right.$, aryl $\left.(\mathrm{dppm}),{ }^{3} J(\mathrm{H}-\mathrm{H})=7.52 \mathrm{~Hz}\right], 7.29[\mathrm{~m}, 8 \mathrm{H}$, aryl (dppm)], $7.29\left[\mathrm{t}, 16 \mathrm{H}\right.$, aryl (dppm), $\left.{ }^{3} J(\mathrm{HH})=7.47 \mathrm{~Hz}\right], 7.38[\mathrm{~m}$, $8 \mathrm{H}$, aryl $(\mathrm{dppm})] \cdot-{ }^{13} \mathrm{C}\left\{{ }^{1} \mathrm{H}\right\}$ NMR $\left(62.9 \mathrm{MHz}, \mathrm{CD}_{3} \mathrm{COCD}_{3}\right): \delta=$ $12.5\left(\mathrm{~s}, \mathrm{SCH}_{2} \mathrm{CH}_{3}\right), 29.4\left(\mathrm{~s}, \mathrm{SCH}_{2}\right), 32.8\left(\mathrm{~s}, \mathrm{CH}_{3}\right), 46.1$ [quint, $\left.\mathrm{CH}_{2}(\mathrm{dppm}), J(\mathrm{PC})=12.05 \mathrm{~Hz}\right], 128.9,129.5$ (quint, $p-\mathrm{C}_{6} \mathrm{H}_{5}, \mathrm{~N}=$ $2.5 \mathrm{~Hz}), 131.1,131.8\left(\mathrm{~s}, m-\mathrm{C}_{6} \mathrm{H}_{5}\right), 132.6$ (quint, ipso- $\mathrm{C}_{6} \mathrm{H}_{5}, N=$ $12.6 \mathrm{~Hz}$ ), 133.2 (quint, ipso- $\mathrm{C}_{6} \mathrm{H}_{5}, N=11.5 \mathrm{~Hz}$ ), 133.7 (quint, $o$ $\mathrm{C}_{6} \mathrm{H}_{5}, N=3.1 \mathrm{~Hz}$ ), 134.0 (quint, $o-\mathrm{C}_{6} \mathrm{H}_{5}, N=2.9 \mathrm{~Hz}$ ), 168.3 [quint, $\mathrm{C}_{\gamma},{ }^{4} J(\mathrm{PC})=1.65 \mathrm{~Hz}$ ], 172.1 [quint, $\mathrm{C}_{\beta},{ }^{3} J(\mathrm{PC})=2.3 \mathrm{~Hz}$ ], 286.2 [quint, $\mathrm{C}_{u},{ }^{2} J(\mathrm{PC})=13.6 \mathrm{~Hz}$ ]. $-{ }^{31} \mathrm{P}\left\{{ }^{1} \mathrm{H}\right\} \quad \mathrm{NMR}$ (101.3 MHz): $\delta=-12.5$ [s, P(dppm)]. - IR (KBr): $\tilde{v}=1943$ (vs, CCC). $-\mathrm{UV} / \mathrm{Vis}\left(\mathrm{CH}_{3} \mathrm{CN}\right): \lambda_{\max }(\log \varepsilon)=232 \mathrm{~nm}$ (4.643), 261 (4.556), 320 (sh, 3.908), 460 (3.892), 633 (sh, 3.410), 675 (3.505). $\left(\mathrm{CH}_{2} \mathrm{Cl}_{2}\right): \lambda_{\max }(\log \varepsilon)=238 \mathrm{~nm}(4.544), 266$ (4.653), 462 (3.924), 635 (sh, 3.360), 686 (3.467). $-\mathrm{C}_{56} \mathrm{H}_{52} \mathrm{ClF}_{6} \mathrm{P}_{4} \mathrm{RuSSb}$ (1253.2): calcd. C 53.67, H 4.18; found C 53.83, H 4.33.

Preparation of trans- $\left[\mathrm{ClRu}(\mathrm{dppm})_{2}=\mathrm{C}=\mathrm{C}=\mathrm{C}(\mathrm{SMe}) \mathrm{C}_{4} \mathrm{H}_{7}\right]^{+} \mathrm{SbF}_{6}{ }^{-}$ (3b): To a suspension of $172 \mathrm{mg}(0.18 \mathrm{mmol})$ of 1 and $204 \mathrm{mg}$ ( $0.79 \mathrm{mmol}$ ) of $\mathrm{NaSbF}_{6}$ in $40 \mathrm{~mL}$ of $\mathrm{CH}_{2} \mathrm{Cl}_{2}$, excess butadiyne (ca. $600 \mu \mathrm{L}$ ) was added by syringe. After the colour of the suspension had changed to green, $120 \mu \mathrm{L}(1.09 \mathrm{mmol})$ of $\mathrm{MeSC}_{3} \mathrm{H}_{5}$ was added by syringe. The solution was stirred at room temperature for $17 \mathrm{~h}$, filtered through a cannula, and the solvent was removed in vacuo. The crude product was dissolved in the minimum volume of $\mathrm{CH}_{2} \mathrm{Cl}_{2}$ and this solution was slowly added to $30 \mathrm{~mL}$ of vigorously stirred hexanes. After stirring for $20 \mathrm{~min}$, the solvent was removed by filter cannula and the green precipitate was washed with a further $20 \mathrm{~mL}$ of hexanes and dried in vacuo; yield $188 \mathrm{mg}(89 \%)$. $-{ }^{1} \mathrm{H}$ NMR $\left(\mathrm{CDCl}_{3}\right): \delta=1.16(\mathrm{~s}, 3 \mathrm{H}, \mathrm{SMe}), 1.47\left[\mathrm{t}, 2 \mathrm{H}, \mathrm{CH}_{2}\right.$, $J(\mathrm{HH})=7.92 \mathrm{~Hz}], 1.74\left(\mathrm{~m}, 2 \mathrm{H}, \mathrm{CH}_{2}\right), 4.84[\mathrm{ddt}, 1 \mathrm{H},=\mathrm{CH}$, ${ }^{3} J(\mathrm{HH}$-trans $\left.)=17.04 \mathrm{~Hz},{ }^{2} J(\mathrm{HH})={ }^{4} J(\mathrm{HH})=1.6 \mathrm{~Hz}\right], 4.97[\mathrm{dd}$, $\left.1 \mathrm{H},=\mathrm{CH},{ }^{3} J(\mathrm{HH}-\mathrm{cis})=10.34 \mathrm{~Hz},{ }^{2} J(\mathrm{HH})=1.6 \mathrm{~Hz}\right], 4.98$ [dquint, $2 \mathrm{H}, \mathrm{CH}_{2}(\mathrm{dppm}), J(\mathrm{HH})=15.23 \mathrm{~Hz},{ }^{2} J(\mathrm{PH})={ }^{4} J\left(\mathrm{P}^{\prime} \mathrm{H}\right)=$ $4.22 \mathrm{~Hz}$ ], 5.28 [dquint, $2 \mathrm{H}, \mathrm{CH}_{2}(\mathrm{dppm}), J(\mathrm{HH})=15.23 \mathrm{~Hz}$, $\left.{ }^{2} J(\mathrm{PH})={ }^{4} J\left(\mathrm{P}^{\prime} \mathrm{H}\right)=4.87 \mathrm{~Hz}\right], 5.43\left[\mathrm{ddt}, 1 \mathrm{H},=\mathrm{CH},{ }^{3} J(\mathrm{HH}-\right.$ trans $)=17.04 \mathrm{~Hz},{ }^{3} J(\mathrm{HH}-$ cis $\left.)=10.34 \mathrm{~Hz},{ }^{2} J(\mathrm{HH})=7.92 \mathrm{~Hz}\right]$, $7.11\left[\mathrm{t}, 8 \mathrm{H}, \operatorname{aryl}(\mathrm{dppm}),{ }^{3} J(\mathrm{HH})=7.50 \mathrm{~Hz}\right], 7.20[\mathrm{br}, 8 \mathrm{H}$, ar$\mathrm{yl}(\mathrm{dppm})], 7.29-7.40[\mathrm{~m}, 16 \mathrm{H}$, $\operatorname{aryl}(\mathrm{dppm})], 7.43[\mathrm{~m}, 8 \mathrm{H}$, aryl (dppm)]. $-{ }^{13} \mathrm{C}\left\{{ }^{1} \mathrm{H}\right\}$ NMR $\left(62.9 \mathrm{MHz}, \mathrm{CD}_{3} \mathrm{COCD}_{3}\right): \delta=16.8$ (s, $\left.\mathrm{SCH}_{3}\right), 32.2\left(\mathrm{~s}, \mathrm{SCH}_{2}\right), 45.0\left(\mathrm{~s}, \mathrm{CH}_{2}\right), 47.1$ [quint, $\mathrm{CH}_{2}(\mathrm{dppm})$, $J(\mathrm{PC})=12.0 \mathrm{~Hz}$ ], $116.2\left(\mathrm{~s},=\mathrm{CH}_{2}\right), 128.2,128.8$ (quint, $p-\mathrm{C}_{6} \mathrm{H}_{5}$, $N=2.5 \mathrm{~Hz}$ ), $130.5,131.1$ (s, $m-\mathrm{C}_{6} \mathrm{H}_{5}$ ), 131.2 (quint, ipso- $\mathrm{C}_{6} \mathrm{H}_{5}$, $N=12.5 \mathrm{~Hz}$ ), 132.4 (quint, ipso- $\mathrm{C}_{6} \mathrm{H}_{5}, N=11.5 \mathrm{~Hz}$ ), 132.9 (quint, $o-\mathrm{C}_{6} \mathrm{H}_{5}, N=3.1 \mathrm{~Hz}$ ), 133.2 (quint, $o-\mathrm{C}_{6} \mathrm{H}_{5}, N=2.8 \mathrm{~Hz}$ ), 135.4 $(\mathrm{s},=\mathrm{CH}), 169.5$ [quint, $\mathrm{C}_{\beta},{ }^{3} J(\mathrm{PC})=2.2 \mathrm{~Hz}$ ] 171.1 [quint, $\mathrm{C}_{\gamma}$, ${ }^{4} J(\mathrm{PC})=1.5 \mathrm{~Hz}$ ], 283.5 [quint, $\left.\mathrm{C}_{a},{ }^{2} J(\mathrm{PC})=13.4 \mathrm{~Hz}\right] .-{ }^{31} \mathrm{P}\left\{{ }^{1} \mathrm{H}\right\}$ NMR (101.3 MHz): $\delta=-12.5[\mathrm{~s}, \mathrm{P}(\mathrm{dppm})] .-\mathrm{IR}(\mathrm{KBr}): \tilde{v}=1940$ (vs, CCC). - UV/Vis $\left(\mathrm{CH}_{3} \mathrm{CN}\right): \lambda_{\max }(\log \varepsilon)=232 \mathrm{~nm}(4.806), 270$ (4.628), 465 (4.210), 663 (3.025); $\left(\mathrm{CH}_{2} \mathrm{Cl}_{2}\right): \lambda_{\max }(\log \varepsilon)=236 \mathrm{~nm}$ (4.681), 272 (4.623), 345 (sh, 3.544), 466 (4.211), 670 (2.653). $\mathrm{C}_{58} \mathrm{H}_{54} \mathrm{ClF}_{6} \mathrm{P}_{4} \mathrm{RuSSb}$ (1279.3): calcd. C 54.46, H 4.25; found $\mathrm{C}$ 54.74, H 4.28.

Preparation of trans- $\left.\mid \mathrm{ClRu}(\mathrm{dppe})_{2}=\mathrm{C}=\mathrm{C}=\mathrm{C}\left(\mathrm{SC}_{3} \mathrm{H}_{5}\right) \mathrm{C}_{4} \mathrm{H}_{7}\right]^{+}$ $\mathrm{CF}_{3} \mathrm{SO}_{3}{ }^{-}$(3c): A solution of $42 \mathrm{mg}(41 \mu \mathrm{mol})$ of [ClRu(dppe $\left.)_{2}\right]^{+}$ $\mathrm{CF}_{3} \mathrm{SO}_{3}{ }^{-[21]}$ in $\mathrm{CDCl}_{3}$ was treated with excess butadiyne. After 
$30 \mathrm{~min}, 25 \mu \mathrm{L}$ of $\mathrm{S}\left(\mathrm{C}_{3} \mathrm{H}_{5}\right)_{2}(0.19 \mathrm{mmol})$ was added by means of a syringe. The progress of the reaction was monitored by ${ }^{31} \mathrm{P}-\mathrm{NMR}$ spectroscopy. After a further $30 \mathrm{~min}, 3 \mathrm{c}$ was the only identifiable product. The solution was transferred to a Schlenk tube and the solvent was removed in vacuo. Recrystallization from $\mathrm{CH}_{2} \mathrm{Cl}_{2} / \mathrm{Et}_{2} \mathrm{O}$ afforded deep-red crystals. A further crop of microcrystals was obtained by concentration of the mother liquor; total yield $41 \mathrm{mg}$ $(84 \%),-{ }^{1} \mathrm{H} \mathrm{NMR}\left(\mathrm{CDCl}_{3}\right): \delta=1.97$ [br. d, $2 \mathrm{H}, \mathrm{SCH}_{2}, J(\mathrm{HH})=$ $6.44 \mathrm{~Hz}$ ], 2.21 [br. t, $2 \mathrm{H}, \mathrm{CH}_{2}, J(\mathrm{HH})=7.83 \mathrm{~Hz}$ ], $2.33(\mathrm{~m}, 2 \mathrm{H}$, $\mathrm{CH}_{2}$ ), 2.76 [br. t, $2 \mathrm{H}, \mathrm{CH}_{2}$ (dppe)], 3.00 [br. m, $2 \mathrm{H}, \mathrm{CH}_{2}$ (dppe)], 4.76 [ddt, $1 \mathrm{H},=\mathrm{CH},{ }^{3} J(\mathrm{HH}$-trans $)=16.52 \mathrm{~Hz},{ }^{2} J(\mathrm{HH})=$ $\left.{ }^{4} J(\mathrm{HH})=1.4 \mathrm{~Hz}\right], 4.93\left[\mathrm{ddt}, 1 \mathrm{H},=\mathrm{CH},{ }^{3} J(\mathrm{HH}-c i s)=9.92 \mathrm{~Hz}\right.$, $\left.{ }^{2} J(\mathrm{HH})={ }^{4} J(\mathrm{HH})=1.5 \mathrm{~Hz}\right], 4.98-5.11(\mathrm{~m}, 3 \mathrm{H},=\mathrm{CH}), 5.75(\mathrm{~m}$, $1 \mathrm{H},=\mathrm{CH}), 6.92\left[\mathrm{t}, 8 \mathrm{H}, \operatorname{aryl}(\mathrm{dppe}),{ }^{3} J(\mathrm{H}-\mathrm{H})=7.55 \mathrm{~Hz}\right]$, 7.04-7.14 [m, $24 \mathrm{H}$, aryl(dppe)], $7.22\left[\mathrm{t}, 8 \mathrm{H}\right.$, aryl(dppe), ${ }^{3} J(\mathrm{H}-$ $\mathrm{H})=7.23 \mathrm{~Hz}], 7.32[\mathrm{~m}, 8 \mathrm{H}$, aryl(dppe) $] .-{ }^{13} \mathrm{C}\left\{{ }^{1} \mathrm{H}\right\} \mathrm{NMR}$ $\left(62.9 \mathrm{MHz}, \mathrm{CDCl}_{3}\right): \delta=29.8$ [quint, $\mathrm{CH}_{2}$ (dppe), $N(\mathrm{PC})=$ $11.6 \mathrm{~Hz}], 32.3,36.5,45.1\left(\mathrm{~s}, \mathrm{CH}_{2}\right), 116.8,120.6\left(\mathrm{~s},=\mathrm{CH}_{2}\right), 127.7$ 128.6 (quint, $p-\mathrm{C}_{6} \mathrm{H}_{5}, \mathrm{~N}=2.4 \mathrm{~Hz}$ ), 129.4 (=CH), 130.2, $131.0(m-$ $\mathrm{C}_{6} \mathrm{H}_{5}$ ), 132.5 (quint, ipso- $\mathrm{C}_{6} \mathrm{H}_{5}, N=11.6 \mathrm{~Hz}$ ), 133.1 (quint, ipso$\mathrm{C}_{6} \mathrm{H}_{5}, N=11.0 \mathrm{~Hz}$ ), 132.3 (quint, $o-\mathrm{C}_{6} \mathrm{H}_{5}, N=3.0 \mathrm{~Hz}$ ), 133.8 (quint, $\left.o-\mathrm{C}_{6} \mathrm{H}_{5}, N=2.6 \mathrm{~Hz}\right), 136.0(\mathrm{~s},=\mathrm{CH}), 169.8,170.2\left(\mathrm{C}_{\beta}, \mathrm{C}_{\gamma}\right)$ 285.1 [quint, $\mathrm{C}_{\boldsymbol{u}},{ }^{2} J(\mathrm{PC})=13.2 \mathrm{~Hz}$ ]. $\quad{ }^{31} \mathrm{P}\left\{{ }^{1} \mathrm{H}\right\} \quad \mathrm{NMR}$ (101.3 MHz): $\delta=42.5$ [s, P(dppm)]. - IR (KBr): $\tilde{v}=1939$ (vs, CCC). $-\mathrm{UV} / \mathrm{Vis}\left(\mathrm{CH}_{3} \mathrm{CN}\right) \lambda_{\max }(\log \varepsilon)=231 \mathrm{~nm}$ (4.706), 265 (4.628), 368 (3.455), 471 (4.230), 681 (2.332); $\left(\mathrm{CH}_{2} \mathrm{Cl}_{2}\right): \lambda_{\max }(\log$ $\varepsilon)=267$ (4.623), 370 (3.470), 475 (4.230), 695 (2.380). $\mathrm{C}_{63} \mathrm{H}_{60} \mathrm{CIF}_{3} \mathrm{O}_{3} \mathrm{P}_{4} \mathrm{RuS}_{2}$ (1246.7): calcd. C 60.70, $\mathrm{H} 4.85$; found $\mathrm{C}$ $60.76, \mathrm{H} 4.88$.

\section{Acknowledgments}

This work was supported by the Deutsche Forschungsgemeinschaft, the Fonds der Chemischen Industrie, Prof. Dr. W. Kaim, and the Institut für Anorganische Chemie der Universität Stuttgart. I also wish to thank Mr. cand. chem. Matthias Wanner for the recording of the EPR spectra and Mr. Dirk Weber for his contributions as part of an advanced laboratory course.
[1] M. I. Bruce, Chem. Rev. 1998, 98, 2599.

[2] A butatrienylidene six-electron donor ligand in a cluster compound has been communicated: C. J. Adams, M. I. Bruce, B. W. Skelton, A. H. White, Chem. Commun. 1996, 2663

[3] J. P. Selegue, Organometallics 1982, I, 217.

[4] M. I. Bruce, P. Hinterding, M. Ke, P. J. Low, B. W. Skelton, A. H. White, Chem. Commun. 1997, 715.

[5] [5a] M. I. Bruce, P. Hinterding, P. J. Low, B. W. Skelton, A. H. White, Chem. Commun. 1996, 1009. - [5b] M. I. Bruce, P. Hinterding, P. J. Low, B. W. Skelton, A. H. White, J. Chem. Soc., Dalton Trans. 1998, 467. - ${ }^{[5 \mathrm{c}]}$ V. Guillaume, P. Thominot, F. Coat, A. Mari, C. Lapinte, J. Organomet. Chem. 1998, 565, 75 .

[6] [6a] R. F. Winter, F. M. Hornung, Organometallics 1997, 16 4248. - [6b] R. F. Winter, F. M. Hornung, to be published in Organometallics.

[7] R. F. Winter, Chem. Commun. 1998, 2209.

[8] D. Touchard, N. Pirio, L. Toupet, M. Fettouhi, L. Ouahab, P. H. Dixneuf, Organometallics 1995, 14, 5263.

[9] D. Touchard, N. Pirio, P. H. Dixneuf, Organometallics 1995, 14,4920 .

[10] E. O. Fischer, H. J. Kalder, A. Frank, F. H. Köhler, G. Huttner, Angew. Chem. 1976, 88, 683; Angew. Chem. Int. Ed. Engl. 1976, 33,1360 .

[11] [11a] R. Aumann, B. Jasper, R. Fröhlich, Organometallics 1995, 14, 3173. - [11b] G. Roth, H. Fischer, Organometallics 1996, 15,1139 .

[12] P. T. Czech, X.-Q. Ye, R. F. Fenske, Organometallics 1990, 9, 2016.

[13] O. J. Scherer, J. Schwalb, H. Swarowsky, G. Wolmershäuser, W. Kaim, R. Gross, Chem. Ber. 1988, 121, 443.

[14] M. Tamm, T. Jentzsch, W. Werncke, Organometallics 1997, 16, 1418.

[15] K. J. Harlow, A. F. Hill, J. D. E. T. Wilton-Ely, J. Chem. Soc., Dalton Trans. 1999, 285.

[16] [16a] M. A. Esteruelas, A. V. Gómez, A. M. López, J. Modrego, E. Oñate, Organometallics 1997, 16, 5826. - [16b] V. Cadierno, M. P. Gamasa, J. Gimeno, M. González-Cueva, E. Lastra, J. Borge, S. García-Granda, E. Pérez-Carreño, Organometallics 1997, 16, 2137

[17] I. P. Evans, A. Spencer, G. Wilkinson, J. Chem. Soc., Dalton Trans. 1973, 204.

[18] B. Chaudret, G. Commenges, R. Poilblanc, J. Chem. Soc., Dalton Trans. 1984, 1635.

[19] K. K. Georgieff, Y. Richard, Can. J. Chem. 1958, 36, 1280.

[20] R. F. Winter, G. Wolmershäuser, J. Organomet. Chem. 1998, $570,201$.

[21] J. R. Polam, L. C. Porter, J. Coord. Chem. 1993, 109.

Received May 19, 1999

[I99176] 